\title{
Predicting post-war US recessions: A probit modelling approach
}

Constantinos Alexiou ${ }^{a, *}$, Emmanouil Trachanas ${ }^{b}$

${ }^{a}$ Cranfield School of Management, Cranfield University, Cranfield MK43 OAL, UK. E-mail:

constantinos.alexiou@cranfield.ac.uk. *Corresponding author.

${ }^{\mathrm{b}}$ Oxford Brookes Business School, Oxford Brookes University, Oxford OX3 OBP, UK. E-mail: etrachanas@brookes.ac.uk.

\begin{abstract}
This paper investigates the factors associated with the occurrences of US recessions over the period 1963Q1 to 2018Q2 using multivariate probit models. The evidence suggests that the probability of a recession decreases with higher profitability, as implied by the proponents of the Marxian tradition. Equally significant are the results that relate to manufacturing activity, investment, and inflation. The theoretical argument however, of those who regard the burgeoning growth of private credit as a factor triggering recessions, is not supported by our findings. Finally, interest rates, Tobin's Q, and labour's share of income are not statistically significant, hence implying that the likelihood of these being closely associated with US economic recessions is rather slim.
\end{abstract}

Keywords: US recessions; profitability; probit models JEL Classifications: B50; B51; D33; E32 


\section{Introduction}

The rate of profit, according to Marx, is a key variable responsible for wide fluctuations in the economic performance of capitalist economic systems. High profitability has a profound impact galvanizing economic activity leading to the creation of employment and higher standards of living. Dwindling profitability however, ushers in a cycle of stagnation and recession/depression wherein investment activity stalls, unemployment increases and living standards decline. In the realm of his analysis Marx (1997) unequivocally seconded that the inherent proclivity of the rate of profit to decline when the economy is booming causes recurrent periods of crises and recessions/depressions in capitalism. Within the Marxian theory of surplus and exploitation, the profit-led character of capitalistic economies assumes a prominent role suggesting that investment in an economy depends on profits. As such, profit affects economic activity through boosting investment expenditure.

For Keynesians, economic crises are the outcome of collapsing effective demand, with causality running from investment to profit. In this setting, dwindling investment expenditure creates unemployment which in turn stifles economic activity and consequently income. The notion of the marginal efficiency of capital (MEC) developed by Keynes is tantamount to the analysis of profitability and consistent with the fundamental principle on the direction of causality between investment and saving with the former causing the latter. For Keynes the MEC approach could be used to explain both short- and long-term fluctuations in the level of economic activity. Even though his analysis on the implications of falling MEC is rather succinct it does however provide significant insights and innovations.

In identifying the causes of a falling profit rate various theories have been put forward by Heterodox economists. The most widely argued theory is the so called 'wage-push'/ 'profit squeeze' theory (see for instance Weisskopf, 1979; Glyn and Sutcliffe, 1972). The rationale of this theory lies in the notion that wages increase due to workers' bargaining 
power whilst militancy in the 1960s and 1970s stifled capitalists' profits which in turn led to recessionary bouts. In other words, the struggle of workers demanding higher wages was achieved at the expense of lower rate of profit.

The post-war US economy has been characterized by two successive phases pertaining to the long-wave-like evolution of its economy (Tsoulfidis and Paitaridis, 2018). The first phase, also known as the 'golden age of accumulation', lasted from the mid to late60s and was immediately followed by the stagflation crisis that lasted until the mid-1980s. The second long-wave phase, also known as 'the neoliberal era', ushered in a period of economic exuberance reaching its peak just before the end of 2007. Currently, the US economy has been exhibiting signs of recovery, but the grim news is that the economy continues to resist returning to normal pre-2007 growth levels. It is even suggested that the current equilibrium might indeed be the new normal (Eggertsson et al., 2019).

The US rate of profit has been exhibiting a declining trend in the post-war period. In the 1960 s and early 1970s, the observed decline in the profit rate resulted in stagflation which adversely affected the living standards in the years that followed (Moseley, 1992; Tsoulfidis, 2002). The immediate response of many governments to the emerging at the time recessionary cycles was the adoption of expansionary Keynesian policies - i.e. more government spending, lower interest rates - to deal with economic stagnation and increasing unemployment which inevitably led to higher rates of inflation as businesses increased prices at a faster rate to deal with a decreasing profit rate. In the 1980s, the emerging role of financial capitalists in dictating economic policies to reverse the inflationary pressures forced governments to resort to the implementation of contractionary policies, which in turn adversely affected unemployment and living standards.

According to Tsoulfidis and Paitaridis (2018) the two distinctive long-wave phases described above have been consistent with a) the falling rate of US profit and the by 
implication hypothesis of a rising rate of surplus value as well as the simultaneous increase in the value composition of capital, and b) the observed stagnation in real net profits.

Furthermore, a falling rate of profit coupled with expansion of unproductive investment expenditures constitutes an explosive mix in the evolution of the next cycle of economic activity.

Using two measures of profitability in a probabilistic framework of analysis this paper breaks new ground by investigating empirically the likelihood that profitability contributes to recession occurrences in the US business cycle. To this objective, we adopt a probit modelling approach for the US economy using quarterly data for the period 1963Q1-2018Q2. The results suggest that increasing profitability reduces the likelihood of a recession whilst the growth of credit, contrary to the conventional wisdom, is found to be insignificant. The assessment of our estimations confirms the predictive performance of our models and the validity of the yielding evidence.

The rest of the paper is organized as follows: Section 2 elaborates on the theoretical approaches encountered in the extant literature whilst Section 3 discusses the methodological framework adopted for the empirical investigation. Section 4 presents the data and the specification of the models and Section 5 discusses the results. Finally, Section 6 provides some concluding remarks.

\section{Theoretical background}

The three dominant Marxian theories of economic crises revolve around a) the lack of effective demand - underconsumption theory, b) the 'profit squeeze' approach, and c) the falling rate of profit thesis. The underconsumption theory suggests that within capitalism at the initial monopoly-finance stage, the tendency to produce too much output will be met by deficient demand, i.e. not enough demand to absorb that output (see, Baran and Sweezy, 
1966; Clarke, 1994). This theory is premised on the notion that the class system existing in capitalism in conjunction with the inherently unequal distribution of income adversely affects wages and therefore the purchasing power of the working class. As a result, the demand gap arising from either low consumption demand or low investment demand due to overaccumulation of capital in view of non-profitable investment opportunities, leads to slow growth of economic activity and inevitably stagnation.

The 'profit squeeze' approach claims that as the working class strengthens its bargaining power in the workplace, higher wage growth and increasing share of income put pressure on the profit share, hence causing a profit squeeze that may even threaten the viability of the system (see Glyn and Sutcliffe, 1972; Boddy and Crotty, 1975; Bowles et al., 1986, 1989, 1990; Weisskopf et al., 1987; Maniatis, 2012).

The law of the falling rate of profit suggests that one of the unintended results of competition within capitalism is the excessive mechanization and capitalization (i.e., a rising capital-output ratio) of the labour process which destroys value created by labour during the process of production. This is further exacerbated in the post-war period by an increase in unproductive labour, squeezing further the labour's value and surplus value, hence leading to a falling rate of profit. In this context, despite the rising rate of surplus value arising from productivity gains, the increasing organic and materialized (capital-output ratio) composition of capital in conjunction with the increase of unproductive labour cause the rate of profit to fall (Moseley, 1992; Shaikh and Tonak, 1994; Mohun, 2005).

Despite the fact that Keynes did not explicitly addressed the impact of falling profitability in his analytical framework, he very eloquently related the MEC to fluctuations in economic activity when he wrote that "today and presumably for the future the schedule of the marginal efficiency of capital is, for a variety of reasons, much lower than it was in the nineteenth century" (Keynes, 1936, p. 308). Keynes regarded falling profitability beyond a 
certain point as one of the main causes of economic depressions and in the General Theory of Employment, Interest and Money devoted two chapters (11 and 12) to provide a more insightful explanation of the occurrence and regularity of business fluctuations - as well as the depression of the 1930s - both in the short- as well as in the long-run.

Currently, the changing landscape of capitalism has been widely attributed to the rise of neoliberalism, globalization, and financialization. In an attempt to describe the transformation of capitalism, Epstein $(2005$, p. 3) provided a definition according to which "financialization means the increasing role of financial motives, financial markets, financial actors and financial institutions in the operation of the domestic and international economies". In this context, numerous books and academic papers have been written to outline the new landscape of capitalism but there is not a common agreement on either the definition of financialization or its significance. For Krippner (2004, p. 14), financialization refers to a "pattern of accumulation in which profit making occurs increasingly through financial channels rather than through trade and commodity production". In other words, the Marxian accumulation theory is sidelined only to give way to the notion that finance is the new source for profit. As such, the speculative nature of financial capital assumes a key role and is responsible for the propagation of crises in capitalism.

According to Mavroudeas and Papadatos (2018), the financialization hypothesis is indeed a popular thesis amidst heterodox and mainstream economics, however it leads into a 'blind valley'. They argue that "the spectacular ballooning of the financial system during the recent decades of weak profitability and accumulation does not constitute a new epoch, let alone a new capitalism. Instead, it represents a familiar capitalist response to periods of weak profitability. This does not preclude the proliferation of new financial instruments, which lend specific new forms to a well-known capitalist process. The Marxist theory of crisis 
and fictitious capital offers an analytically and empirically superior understanding of this process" (2018, p.451).

Undoubtedly, dwindling profitability might not be the only factor that causes crises and stagnation in capitalist economies (Edvinsson, 2005). Ramirez (2007) for instance, apart from identifying deficient demand as one of the culprits for poor economic performance, goes on to argue that both the disproportionality in production as well as the chaotic nature of capitalism should be considered when explaining economic fluctuations.

On a different note, Brenner (2006) in his critique to the theoretical assumption of the declining US rate of profit argued that there is a fundamental flaw in this theory as it cannot explain the low levels of the rate of profit for such a long period or the partially recovered profit from the prior decline. If the cause of the decline of the rate of profit was to be attributed to the increase in workers' bargaining power due to relatively low levels of unemployment in the late 1960s and early 1970s, then why have profits not recovered given the higher levels of unemployment since the 1970s? Moseley (2005) in responding to Brenner's theory of profit argued that it is distinctly different from Marx's theory of profit which is predominately determined by the surplus labour of workers and has never been alluded to by Brenner.

Furthermore, post-Keynesian economists dismiss Marx's theory of value - based on the exploitation of labour and the law of the tendency of the rate of profit to fall - and instead argue that crises are the results of distributional factors caused by wages being too low (wage-led) or profits being too low (profit-led) (see, Minsky, 1986; Onaran and Galanis, 2012; Stockhammer, 2011). They consider debt to be a key factor that potentially leads to economic instability, hence arguing for a debt-led rather than an investment-led growth explanation of crises in capitalism. In this context, crises especially after the emergence of 
neoliberalism in the 1980s have been mainly 'wage-led', wherein increasing levels of debt act as the compensating mechanism that provides liquidity to low-wage workers.

On the policy front, Krugman (2015), by rationalizing the US slump in 1937-38 that was precipitated by the austerity policies introduced by Roosevelt, called for more government spending through borrowing, i.e. expansionary Keynesian policies, and not fiscal austerity. The traditional Keynesian argument in this regard rests in the causal dimension between investment and profit. For Keynes (1936), the direction of causality runs from investment to profit suggesting that the subjective decisions of entrepreneurs are influenced by 'animal spirits' and the expectations of the return on capital drive future investment. For Marxian economists however, the causal dimension between investment and profit runs in the opposite way with investment depending on profit and profit depending on the exploitation of labour and its ensuing appropriation by capitalists (Roberts, 2017). As such, the Marxian causal analysis is based on an explicit system of class society existing in capitalism and not on some ad hoc behavioural analysis of individuals that hinders our capacity to lucidly comprehend the laws dictate the evolutionary nature of capitalism.

\section{Methodological framework}

In so far as capitalism is closely associated with profitability which in turn depends on capital accumulation, the aggregate profit rate is a key variable in the context of Marxian political economy. According to Basu (2013, p. 293) "the profit rate is measured as the ratio of profit income and the capital advanced that has been used to generate that profit income. There are two different ways to measure the capital advanced: (a) as the historical cost value of the stock of capital, i.e., valuing elements of the capital stock at the prices at which they were purchased, and (b) as the replacement (or current) cost value of the stock of capital, i.e., valuing elements of the capital stock at prices at which they could be purchased in the market 
in the current period. On the empirical front, the majority of Marxian economists tend to use replacement cost valuation of the capital stock (see Moseley, 1992; Kotz, 2009; Shaikh, 2010; Dumenil and Levy, 2011), whilst there are others who use the historical cost valuation (see Kliman, 2011).

This study uses two different proxies for profitability: the net operating surplus (rate of profit, $R O P)^{1}$, and the incremental rate of profit $(I R O P)$. More specifically, net operating surplus shows business income once the costs of compensation of employees, taxes on production and imports less subsidies, and consumption of fixed capital are subtracted from value added - but before subtracting financing costs and business transfer payments. The incremental rate of profit variable constitutes an interesting innovation in our estimations as it obviates the need to deal with theoretical and empirical issues arising from the measurement of capital stock (Alexiou et al., 2016). The underlying rationale of the way the incremental rate of profit is constructed, i.e. the ratio of change in real gross profits over the real gross investment of the last period, is predicated on the notion that recent returns on investment, as opposed to returns on all past investment, act as catalyst for new investment activity (Shaikh, 1995).

Alexiou et al. (2016) formulate the current period flow of profits $\Pi_{t}$ as follows:

$$
\Pi_{t}=\rho I_{t-1}+\Pi^{*}
$$

According to Equation (1), there are two sources that contribute to the current period flow of profits $\Pi_{t}$ : the profits on most recent investment $I_{t-1}$ multiplied by some markup $\rho$, and the

\footnotetext{
${ }^{1}$ The literature is inundated with many ways of measuring $R O P$ and the potential implications that the alternative measures might have for the economy. For instance, when considering constant capital in the measure of $R O P$, residential, government assets or other non-profit activities can be excluded. Alternative measures could potentially focus on the business sector and exclude the wages of public sector workers or even exclude the wages of unproductive workers or measure profit before or after tax. Some propose a more simplistic approach where $R O P$ consists of net national income devoid of depreciation and employee compensation. Others argue that the way you measure ROP ala Marx does not make much of a difference in the case of the US economy (see for instance Dumenil and Levy, 2002).
} 
stream of profits that accumulate to a firm from all other past investments $\Pi^{*}$. By subtracting lagged profits from both sides of Equation (1) we get:

$$
\Pi_{t}-\Pi_{t-1}=\rho I_{t-1}+\left(\Pi^{*}-\Pi_{t-1}\right) \text { or } \Delta \Pi_{t}=\rho I_{t-1}+\left(\Pi^{*}-\Pi_{t-1}\right)
$$

In Equation (2), the term in parentheses $\Pi^{*}-\Pi_{t-1}$ is expected to be smaller than the term $\rho I_{t-1}$, i.e. the total effect is negligible and therefore lagged profits can be safely disregarded (Shaikh, 1995; Elton et al., 2003, ch.18, p.14). It is therefore reasonable to assume that the current rate of return on new investment can be expressed as:

$$
\rho \approx \frac{\Delta \Pi_{t}}{I_{t-1}}
$$

This is the incremental rate of profit $(I R O P)$ and is defined as the ratio of the current change in gross real profits to gross real investment lagged by one period. According to Alexiou et al. (2016) IROP refers to short-run profitability and purports to identify indirectly the profitability of the leading firms (or the regulating capitals) of an economy over the years. In this sense, IROP becomes a more immediate regulator of investment activities, whereas the average rate of profit becomes the long-run regulator of investment flows. IROP is also thought to be closely bound up with the short-run Keynesian index of profitability, i.e. the marginal efficiency of capital.

\section{Data and model specifications}

We explore the determinants of the probability of US recessions over the period 1963Q12018Q2 by utilizing multivariate probit models. The general form of our models is expressed as follows:

$$
R_{t}=\alpha+\beta \mathbf{X}+\varepsilon_{t}
$$

Our dependent variable $R$ is a binary recession indicator series defined as: 


$$
R_{t}=\left\{\begin{array}{l}
1, \text { if the economy is in a recession at time } t \\
0, \text { if the economy is in an expansion at time } t
\end{array}\right.
$$

The binary dependent variable is constructed based on the US National Bureau of Economic Research (NBER) business cycle reference dates as those are defined by NBER's Business Cycle Reference Committee ${ }^{2}$. Figure 1 illustrates graphically the binary dependent variable (i.e., NBER's recession periods) along with the evolution of US real GDP growth for our sample period.

\section{[Figure 1 about here]}

Equation (4) includes a vector $\mathbf{X}$ of independent variables accounting for potential determinants of a recession, consisting of: the credit-to-GDP ratio (CGDP) to capture the increasing role of the financial sector in the economy; the consumer price index rate $(C P I R)$ as a proxy for inflation and macroeconomic stability; the purchasing managers index in manufacturing $(M A)$ as a proxy for business confidence; the gross fixed capital formation growth rate $(I N V R)$ as a measure of investment activity; and the residential property prices index $(H P)$. Table A1 in the Appendix provides a detailed description of all variables and sources.

It should be noted that prior to estimating our models, we have tested our series for unit roots to ensure that the binary choice probabilities are stationary (Regenwetter and Davis-Stober, 2018). Thereby, the resulting first difference transformation ( $\Delta$ ) of some of the variables used in the estimations reflect stationary processes.

We estimate five probit models (Models 1 to 5) where the independent variables capture many of the factors suggested by theory. Each model is estimated with an additional key independent variable. Model 1 includes the first difference in real interest rate $(I R)$ to capture the financial conditions that affect both phases of the business cycle considering that

\footnotetext{
${ }^{2}$ For more details please see https://www.nber.org/cycles/cyclesmain.html.
} 
an increase in interest rates stifles planned investment expenditures, reducing output thereby increasing the unemployment rate, and vice versa. Models 2 and 3 use two measures of profitability proxied by the net operating surplus $(R O P)$ and the incremental rate of profit $(I R O P)$, respectively. Model 4 uses labour's share of income ${ }^{3}$ (LSOI) to capture the bargaining power of workers in setting higher wages, and finally Model 5 includes Tobin's Q $(T O B Q)$ as a broad measure of firms' performance which is defined as the market value of the company divided by the replacement value of the firm's assets. When Tobin's Q is above its long-term mean the market is considered to be overvalued and when it is below, it is considered to be undervalued. Table A2 in the Appendix presents the contemporaneous correlations and shows that high pair-wise correlation coefficients among the explanatory variables are not detected.

We assess our five specifications by first examining a Wald test of whether all predictors' regression coefficients are simultaneously zero and by employing the HosmerLemeshow goodness-of-fit test (Hosmer and Lemeshow, 1980; Lemeshow and Hosmer; 1982) which is based on a comparison of observed and estimated frequencies in groups of observations defined by the estimated probability of the reference outcome. Further, given the binary nature of the dependent variable we also consider the fraction of observations that are actual positives (i.e., recessions) and are correctly identified as such (sensitivity), the fraction of observations that are actual negatives (i.e., non-recessions) and are correctly identified as such (specificity), and the overall rate of correct classification. It is worth noting here that both sensitivity and specificity depend heavily on the distribution of the estimated probabilities in the sample and therefore, in order to obtain the above classifications we have

\footnotetext{
${ }^{3}$ The labour's share of income is a proxy that can capture many aspects of the distributional spectrum. We additionally attempted to employ other proxies such as wages and union density but due to discrepancies in terms of the frequency and the time span of the available data we were unable to incorporate these in our estimations.
} 
used both the standard positive outcome threshold of $0.5(50 \%)$ and additionally, as suggested by Wooldridge (2016, p. 530), a positive outcome threshold of $0.1216(12.16 \%)$ which is the fraction of recessions in our sample.

We additionally present the receiver operating characteristic (ROC) curves which are graphical plots illustrating the diagnostic ability of the predictive models in distinguishing between the true positives and negatives for an entire range of possible cut-off points. A ROC curve plots sensitivity against 1 - specificity while the area under the ROC curve (AUC) ranges from 0.5 to 1.0 and summarizes the predictive information of the ROC curve. The higher the AUC is, the better a model is at predicting 0s as 0s (non-recessions) and $1 \mathrm{~s}$ as $1 \mathrm{~s}$ (recessions).

\section{Empirical results and discussion}

Panel A of Table 1 reports the results of the probit regressions for our five models where a positive coefficient indicates that an increase in the predictor variable leads to an increase in the predicted probability while a negative coefficient indicates a decrease. In all models the common explanatory variables are found to be statistically significant with the exception of one. More specifically, inflation $(C P I R)$ is statistically significant and positive suggesting that an increase in inflation increases the probability of recession, a finding in line with the theoretical argument according to which higher prices lead to reduced demand for products thereby causing economic activity to shrink. The proxy for manufacturing activity as well as business confidence $(M A)$, is found to be statistically significant and negatively associated with the probability of recession. This is in line with the Keynesian approach that is encapsulated in the concept of 'animal spirits' according to which positive expectations about the current business conditions can significantly boost economic activity. In addition, the growth rate of investment $(I N V R)$ is statistically significant and negative indicating that 
increasing investment will be expected to reduce the probability of a recession as it is suggested by the Keynesian multiplier effect on economic activity. Further, the significance and negative coefficient of the change in house prices index $(\triangle H P)$ suggests a reduced probability of recession when property values increase thus contributing to a less recessionary environment. In trying to provide a sensical explanation of this finding one can assume that increasing house prices might indicate that the economy has started moving up the cycle, hence the economy is expanding. In other words, increasing house values, affect GDP growth through consumer spending, the so-called wealth effect. It should be stressed however that many economists (such as Greenspan, 2005; Rajan, 2005; Shiller, 2007) argue that low risk premiums, misalign incentives for risk-taking, and high house prices might precede an economic crisis. Finally, an unexpected but interesting finding is that changes in the credit-toGDP ratio $(\triangle C G D P)$ are statistically insignificant across all estimated models. In an era where the severity of the Great Recession is thought to be primarily caused by 'financial panics' (Bernanke, 2018), this finding merits particular attention in so far as financialization might simply manifest itself as a symptom rather than as a key variable responsible for explaining a potential downswing in the business cycle as suggested by Marxian analysis.

\section{[Table 1 about here]}

Moving our attention to the additional key independent variables we notice that the probability of a US recession declines significantly when both proxies for profitability, i.e. $R O P$ and $I R O P$, increase (Models 2 and 3). These findings are in line with the theoretical arguments on both the falling rate of profit as well as the falling MEC, respectively. However, the measure of the third potential proxy for profitability captured by Tobin's Q $(T O B Q)$, although it bears a negative sign, it is found to be statistically insignificant (Model 5). This might be due to the endogenous nature with respect to managerial decisions where underinvestment inflates Tobin's Q, hence rendering it an inappropriate measure (Dybvig and 
Warachka, 2015). Further, the change in the labour's share of income ( $\Delta L S O I)$ is also found to be statistically insignificant (Model 4) thus suggesting that an increase in workers income might not constitute a sufficient condition that can significantly trigger a recession. Finally, the change in the interest rate $(\Delta I R)$ which in this context purports to also capture the level of risk in the US economy, is found to be insignificant (Model 1) hence suggesting that it does not contribute to the explanatory power of the model in predicting recessions. This finding can be interpreted in many ways, one of which might be the fact that the zero-low-bound (ZLB) interest rate environment that the US economy has been locked in for many years now, has rendered monetary policy ineffective (Kiley and Roberts, 2017).

Panel B of Table 1 presents the conditional marginal effects showing the effect of a unit change in the mean value of the explanatory variables on the probability of a recession. Focusing on Models 2 and 3, the results suggest that if the mean inflation rate increases, the probability of a recession increases by 0.057 and 0.059 , respectively, while the manufacturing activity index has a moderate negative effect (0.005 and 0.006). House prices have a negative effect of 0.026 and 0.028 , respectively, whereas the growth rate of investment is found to be insignificant, suggesting that a unit change in its mean value has no statistically significant impact on the probability of a recession. Of special interest are the marginal effects of the two proxies for profitability, with the results suggesting that if profitability increases by one percent, it will decrease the probability of a recession by 0.001 and 0.015 in Models 2 and 3, respectively. Figures 2 and 3 present the graphs of the marginal effects of the statistically significant variables in Models 2 and 3 on the probability of a recession which further confirm the above findings.

[Figures 2 and 3 about here]

The lower part of Table 1 reports several statistics to assess the predictive performance of our models. The Wald statistics are high in all models indicating that the 
models are statistically significant, that is, they fit significantly better than a model with no predictors. Further, the Hosmer-Lemeshow goodness of fit tests also indicate that the models fit quite well since the null hypothesis that the observed and expected or predicted probabilities are the same across different levels of predicted values, cannot be rejected. With a 0.5 positive outcome threshold, the percentage of recessions that are correctly identified range from $33.33 \%$ to $48.15 \%$ while the overall rate of correct classification ranges from $89.59 \%$ to $91.40 \%$. When using the lower 0.1216 positive outcome threshold (i.e. the fraction of recessions in our sample), the predictive performance of the percentage of recessions that are correctly identified improves substantially, at $88.89 \%$. However, the overall rate of correct classification slightly decreases indicating that false predictions increase. Figure 4 presents the ROC curves for the five models and in all cases the AUC is greater than 0.9 indicating outstanding discrimination between the true positives and negatives for an entire range of possible cut-off points (Hosmer et al., 2013, p. 177). Overall, the above results suggest that the models perform quite well with satisfactory predictive performance.

\section{[Figure 4 about here]}

Finally, we estimate the predicted probabilities using the reported coefficients of Models 2 and 3 (Table 1, Panel A). Figures 5 and 6 graph the predicted probabilities for the 1963Q1-2018Q2 period along with NBER's recession reference periods. We notice that Models 2 and 3 are able to capture all of the recently experienced US recessions further validating the models' predictive performance.

\section{[Figures 5 and 6 about here]}




\section{Conclusions}

In the realm of Heterodox economics, the significant decline in the rate of profit over the last four decades has been regarded as the main culprit, hence causing wide fluctuations in economic activity. In this study, using a probabilistic framework of analysis we provide evidence supporting the view that dwindling profitability can potentially increase the probability of a recession in the USA. Additional evidence suggests that investment expenditure and sanguine business conditions can propel economic activity as well. However, the measure of the increased role of the financial system, i.e. the credit-to-GDP ratio, appears to have no direct bearing on recessions ${ }^{4}$, hence providing support to those who perceive financial panics as a symptom rather than a real cause of US recessions. Finally, interest rates, Tobin's Q, and labour's share of income do not appear to be closely associated with economic recessions in the USA.

Marxian theory suggests that governments do not possess any real economic policies to galvanize economic activity in so far as these policies cannot positively affect the rate of profit and most importantly the ratio of unproductive labour to productive labour. In this setting, an increasing ratio of unproductive labour to productive labour can cause a significant decline of the rate of profit in the future, hence, amplifying its disastrous effects for the economy.

The Keynesian analysis of profitability, via the concept of the marginal efficiency of capital, offers a more subtle explanation of both short- and long-term fluctuations in economic activity. In this context, the evolving nature of the marginal efficiency of capital approach reflects the fundamental principles that lend support to the causal dimension

\footnotetext{
${ }^{4}$ It is worth noting here that previous research has widely supported the idea that credit plays a significant role in business cycles and therefore the fact that the growth of credit is found to be insignificant with regards to the occurrences of US recessions should prompt an in-depth investigation into its effects on expansions and recessions rather than taken at full face value.
} 
between investment and saving, with the former causing the latter. Unlike the Marxian framework of analysis, the Keynesian approach to the proclivity of profitability to fall in the long-run and the ensuing disastrous effects on economic activity has not received enough currency in the extant literature. For Keynes, the notion of long-run falling profitability is conveyed through expectations about future profitability that are reflected by movements in the marginal efficiency of capital which, if it dwindles, reduces the propensity to consume substantially and hence aggregate demand.

Furthermore, Marxian economics suggest that, for capitalist economies to grow, continuous monetary advances are required by capitalists. In this context, the creation of credit serves as an unlimited source of finance for such as an expansion. The way credit is therefore channelled through the economy assumes a prominent role in the determination of capital accumulation. The Marxian perspective treats credit as endogenous to capital accumulation which is determined by credit demand. The interest rate however, is considered to be exogenous, determined by historical, institutional and political factors. In this framework, policies implemented by central banks as instruments in the distribution struggle, are determined by central banks as well as by the attitude of commercial banks towards liquidity and monetary wealth holders. Moreover, according to Marx, the existing capital labour conflict in the labour market determines both the rate of profit and the real wage rate. In contrast, the proponents of effective demand suggest that capital accumulation will be determined by investment decisions which will then impact profits and savings. Therefore, investment decisions are thought to be conditioned by both the rate of interest and the rate of expected profits.

It is envisaged that future research on the interaction between monetary and real forces would be of a great interest to the academic community, which if considered in 
historical perspective, will contribute to a more insightful analysis on the relationship between the rate of profit and economic crises.

\section{Acknowledgements}

We are grateful to two anonymous reviewers for their comments which improved this article. The usual disclaimer applies. 


\section{Appendix}

\section{Table A1}

Description of variables

\begin{tabular}{|c|c|c|}
\hline Variable & Description & Source \\
\hline$R$ & Binary recession indicator series & $\begin{array}{l}\text { National Bureau of Economic Research } \\
\text { https://www.nber.org/cycles/cyclesmain.html } \\
\text { and Federal Reserve Economic Data of the } \\
\text { Federal Reserve Bank of St. Louis } \\
\text { https://fred.stlouisfed.org/series/USRECQP\#0 }\end{array}$ \\
\hline$C G D P$ & $\begin{array}{l}\text { Credit-to GDP ratio (total credit to } \\
\text { private non-financial sector, } \% \text { GDP) }\end{array}$ & $\begin{array}{l}\text { Federal Reserve Economic Data of the } \\
\text { Federal Reserve Bank of St. Louis }\end{array}$ \\
\hline CPIR & Consumer price index ratio & $\begin{array}{l}\text { Federal Reserve Economic Data of the } \\
\text { Federal Reserve Bank of St. Louis }\end{array}$ \\
\hline$M A$ & $\begin{array}{l}\text { Purchasing Managers Index - } \\
\text { Manufacturing }\end{array}$ & Institute for Supply Management (ISM) \\
\hline$I N V R$ & $\begin{array}{l}\text { Gross fixed capital formation growth } \\
\text { rate (nonfinancial corporate business; } \\
\text { gross fixed capital formation with } \\
\text { equity REIT residential structures) }\end{array}$ & $\begin{array}{l}\text { Federal Reserve Economic Data of the } \\
\text { Federal Reserve Bank of St. Louis }\end{array}$ \\
\hline$H P$ & $\begin{array}{l}\text { Residential house prices index (new } \\
\text { 1-family houses, per dwelling) }\end{array}$ & Bank of International Settlements \\
\hline$I R$ & Interest rate (real) & $\begin{array}{l}\text { Federal Reserve Economic Data of the } \\
\text { Federal Reserve Bank of St. Louis }\end{array}$ \\
\hline$R O P$ & $\begin{array}{l}\text { Profit rate (nonfinancial corporations' } \\
\text { sector) }\end{array}$ & $\begin{array}{l}\text { Federal Reserve Economic Data of the } \\
\text { Federal Reserve Bank of St. Louis }\end{array}$ \\
\hline IROR & $\begin{array}{l}\text { Incremental rate of profit per unit of } \\
\text { investment }\end{array}$ & Authors' calculations \\
\hline LSOI & $\begin{array}{l}\text { Labour's share of income (nonfarm } \\
\text { business sector) }\end{array}$ & $\begin{array}{l}\text { Federal Reserve Economic Data of the } \\
\text { Federal Reserve Bank of St. Louis }\end{array}$ \\
\hline$T O B Q$ & Tobin's Q & $\begin{array}{l}\text { Ycharts } \\
\text { https://ycharts.com/indicators/tobins_q }\end{array}$ \\
\hline$R G D P$ & Real gross domestic product growth & $\begin{array}{l}\text { Federal Reserve Economic Data of the } \\
\text { Federal Reserve Bank of St. Louis }\end{array}$ \\
\hline
\end{tabular}

Note: The sample period for all variables is 1963Q1-2018Q2 with the exception of Tobin's Q where data were available for 1963Q1-2017Q4. 
Table A2

Correlation matrix

\begin{tabular}{lllllllllll}
\hline & $\triangle C G D P$ & $C P I R$ & $M A$ & $I N V R$ & $\Delta H P$ & $\Delta I R$ & ROP & IROR & $\Delta L S O I$ & TOBQ \\
\hline$\Delta C G D P$ & 1.00 & & & & & & & & & \\
$C P I R$ & 0.05 & 1.00 & & & & & & & & \\
$M A$ & -0.02 & -0.02 & 1.00 & & & & & & & \\
$I N V R$ & 0.00 & 0.31 & 0.61 & 1.00 & & & & & & \\
$\Delta H P$ & 0.05 & 0.13 & 0.08 & 0.07 & 1.00 & & & & & \\
$\Delta I R$ & 0.04 & 0.14 & 0.51 & 0.38 & 0.15 & 1.00 & & & & \\
$R O P$ & -0.09 & 0.03 & 0.25 & 0.18 & 0.13 & 0.18 & 1.00 & & & \\
$I R O R$ & -0.05 & -0.03 & 0.23 & 0.24 & -0.02 & 0.07 & 0.65 & 1.00 & & \\
$\triangle L S O I$ & 0.08 & -0.01 & 0.01 & 0.03 & -0.03 & -0.02 & -0.40 & -0.34 & 1.00 & \\
TOBQ & -0.00 & -0.57 & 0.06 & -0.09 & 0.07 & -0.01 & -0.06 & -0.06 & 0.01 & 1.00
\end{tabular}




\section{References}

Alexiou, C., Tsaliki, P., Tsoulfidis, L., 2016. Classical theory of investment: panel cointegration evidence from 13 EU countries. Contributions to Political Economy 35(1), 39-56. https://doi.org/10.1093/cpe/bzw004

Baran, P., Sweezy, P., 1966. Monopoly Capital: An Essay on the American Economic and Social Order. Monthly Review Press, New York.

Basu, D., 2013. Replacement versus historical cost profit rates: what is the difference? When Does it Matter? Metroeconomica 64(2), 293-318. https://doi.org/10.1111/meca.12008

Bernanke, B.S., 2018. The real effects of disrupted credit: evidence from the global financial crisis. Brookings Papers on Economic Activity 2018(2), 251-342.

\subsection{3/eca.2018.0012}

Boddy, R., Crotty, J., 1975. Class conflict and macro-policy: the political business cycle. Review of Radical Political Economics 7(1), 1-19. https://doi.org/10.1177/048661347500700101

Bowles, S., Gordon, D.M. and Weisskopf, T.E., 1986. Power and profits: the social structure of accumulation and the profitability of the postwar US economy. Review of Radical Political Economics 18(1-2), 132-167. https://doi.org/10.1177/048661348601800107

Bowles, S., Gordon, D.M. and Weisskopf, T.E., 1989. Business ascendancy and economic impasse: a structural retrospective on conservative economics, 1979-87. Journal of Economic Perspectives 3(1), 107-134. 10.1257/jep.3.1.107

Bowles, S., Gordon, D.M., Weisskopf, T.E., 1990. After the Waste Land. M.E. Sharpe, New York.

Brenner, R., 2006. The Economics of Global Turbulence. Verso, London.

Clarke, S., 1994. Marx’s Theory of Crisis. Basingstoke, Macmillan Press. 
Dumenil, G., Levy, D., 2002. The profit rate: where and how much did it fall? Did it recover? (USA 1948-2000). Review of Radical Political Economics 34(4), 437-461. https://doi.org/10.1177/048661340203400403

Dumenil, G., Levy, D., 2011. The Crisis of Neoliberalism. Harvard University Press.

Dybvig, P.H., Warachka, M., 2015. Tobin's q does not measure firm performance: theory, empirics, and alternatives. Empirics, and Alternatives (March 5, 2015). Available at SSRN: https://ssrn.com/abstract=1562444

Edvinsson, R., 2005. Growth, accumulation, crisis: with new macroeconomic data for Sweden 1800-2000. Doctoral dissertation, Acta Universitatis Stockholmiensis.

Eggertsson, G.B., Lancastre, M., Summers, L.H., 2019. Aging, output per capita, and secular stagnation. American Economic Review: Insights 1(3), 325-342. $\underline{10.1257 / \text { aeri.20180383 }}$

Elton, E., Gruber, M., Brown, S., Goetzmann, W., 2003. Modern Portfolio Theory and Investment Analysis. John Willey \& Sons.

Epstein, G., 2005. Financialization and the World Economy. Edward Elgar, Cheltenham and Northampton.

Glyn, A., Sutcliffe, B., 1972. Capitalism in Crisis. Pantheon Books, New York.

Greenspan, A., 2005. Reflections on central banking. Speech presented at the Jackson Hole Economic Policy Symposium, Jackson Hole, Wyoming, August 26. Available at: https://www.kansascityfed.org/publicat/sympos/2005/pdf/Green-opening2005.pdf

Hosmer, D.W., and Lemeshow, S., 1980. A goodness-of-fit test for the multiple logistic regression model. Communications in Statistics A10, 1043-1069.

Hosmer, D.W., Lemeshow, S., Sturdivant, R.X., 2013. Applied Logistic Regression. Wiley Series in Probability and Statistics. John Wiley \& Sons. 
Keynes, J.M., 1936. The General Theory of Employment, Interest, and Money. Harcourt, Brace \& World, New York.

Kiley, M.T., Roberts, J.M., 2017. Monetary policy in a low interest rate world. Brookings Papers on Economic Activity 2017(1), 317-396. 10.1353/eca.2017.0004

Kliman. A., 2011. The Failure of Capitalist Production: Underlying Causes of the Great Recession. Pluto Press, London.

Kotz, D.M., 2009. The financial and economic crisis of 2008: a systemic crisis of neoliberal capitalism. Review of Radical Political Economics 41(3), 305-317. https://doi.org/10.1177/0486613409335093

Krippner, G., 2004. What is Financialization? Department of Sociology, UCLA, mimeo. Krugman, P., 2015. The case for cuts was a lie. Why does Britain still believe it? The austerity delusion. The Guardian Newspaper, https://www.theguardian.com/business/ng-interactive/2015/apr/29/the-austeritydelusion

Lemeshow, S. and Hosmer, D.W., 1982. A review of goodness of fit statistics for use in the development of logistic regression models. American Journal of Epidemiology 115(1), 92-106. https://doi.org/10.1093/oxfordjournals.aje.a113284

Maniatis, T., 2012. Marxist theories of crisis and the current economic crisis. In Forum for Social Economics 41(1), 6-29). https://doi.org/10.1007/s12143-010-9076-3

Marx, K., 1997. Capital: A Critique of Political Economy. Vol. III. International Publishers [1894], New York.

Mavroudeas, S., Papadatos, D., 2018. Is the financialization hypothesis a theoretical blind alley? World Review of Political Economy 9(4), 451-476. https://www.jstor.org/stable/10.13169/worlrevipoliecon.9.4.0451 
Minsky, H., 1986. Stabilizing an Unstable Economy. Yale University Press, New Haven and London.

Mohun, S., 2005. On measuring the wealth of nations: the US economy, 1964-2001.

Cambridge Journal of Economics 29(5), 799-815. https://doi.org/10.1093/cje/bei043

Moseley, F., 1992. The Falling Rate of Profit in the Postwar United States Economy. St. Martin's Press.

Moseley, F., 2005. The decline of the rate of profit in the postwar US economy: a comment on Brenner. Working paper, Mount Holyoke College.

Onaran, Ö. and Galanis, G., 2012. Is aggregate demand wage-led or profit-led? National and global effects (pp. 1-74). ILO Working Papers, Geneva.

Rajan, R., 2005. Has financial development made the world riskier? Working Paper 11728. National Bureau of Economic Research. https://doi.org/10.3386/w11728

Ramirez, M., 2007. Marx, wages, and cyclical crises: a critical interpretation. Contributions to Political Economy 26(1), 27-41. https://doi.org/10.1093/cpe/bzm020

Regenwetter, M., Davis-Stober, C.P., 2018. The role of independence and stationarity in probabilistic models of binary choice. Journal of Behavioral Decision Making 31(1), 100-114. https://doi.org/10.1002/bdm.2037

Roberts, M., 2017. The profit-investment nexus: Keynes or Marx? Conference Paper to Historical Materialism, April 2017, New York.

Shaikh, A., 2010. The first great depression of the 21st Century. In Panitch, L., Albo, G., Chibber, V. (eds), The Crisis this Time: Socialist Register 2011, pp. 44-63. The Merlin Press.

Shaikh, A., Tonak, E.A., 1994. Measuring the Wealth of Nations: The Political Economy of National Accounts. Cambridge University Press, Cambridge. 
Shaikh, A.M., 1995. The stock market and the corporate sector: a profit-based approach. The Jerome Levy Economics Institute Paper (146). Available at SSRN: https://ssrn.com/abstract $=87648$ or http://dx.doi.org/10.2139/ssrn.87648

Shiller, R., 2007. Understanding recent trends in house prices and homeownership. In Housing, Housing Finance, and Monetary Policy. Jackson Hole, Wyoming. https://www.kansascityfed.org/publicat/sympos/2007/PDF/Shiller_0415.pdf

Stockhammer, E., 2011. Wage norms, capital accumulation and unemployment. A Post Keynesian view. Oxford Review of Economic Policy 27(2), 295-311. https://doi.org/10.1093/oxrep/grr013

Tsoulfidis, L., 2002. Rethinking long cycles: are the 1990s the onset of a new golden age of accumulation? In Georgopoulos, T., Paraskevopoulos, C., Smithin, J. (eds), Globalization and Economic Growth. A Critical Evaluation, pp. 81-96. Athenian Policy Forum Press, Toronto.

Tsoulfidis, L., Paitaridis, D., 2018. Capital intensity, unproductive activities and the Great Recession in the US economy. Cambridge Journal of Economics 43, 623-647. https://doi.org/10.1093/cje/bey051

Weisskopf, T.E., 1979. Marxian crisis theory and the rate of profit in the postwar U.S. economy, Cambridge Journal of Economics 3(4), 341-378. https://www.jstor.org/stable/23596415

Weisskopf, T.E., Bowles, S., Gordon, D.M., 1987. Power, accumulation and crisis: the rise and demise of the postwar social structure of accumulation. Union for Radical Political Economy (ed), Imperiled Economy: A Left Perspective. Monthly Review, New York.

Wooldridge, J.M., 2016. Introductory Econometrics: A Modern Approach. 6th edn. Cengage Learning. 
Table 1

Estimation results

Panel A: Probit models

\begin{tabular}{|c|c|c|c|c|c|}
\hline & Model 1 & Model 2 & Model 3 & Model 4 & Model 5 \\
\hline \multirow[t]{2}{*}{$\triangle C G D P$} & 0.057 & 0.061 & 0.055 & 0.084 & 0.072 \\
\hline & (0.174) & $(0.177)$ & $(0.174)$ & (0.174) & $(0.169)$ \\
\hline \multirow[t]{2}{*}{ CPIR } & $1.034 * * *$ & $1.043 * * *$ & $0.957 * * *$ & $1.009 * * *$ & $0.894 * * *$ \\
\hline & $(0.232)$ & $(0.214)$ & $(0.210)$ & $(0.201)$ & $(0.221)$ \\
\hline \multirow[t]{2}{*}{$M A$} & $-0.072 * *$ & $-0.085 * *$ & $-0.091 * * * *$ & $-0.091 * * *$ & $-0.086 * * *$ \\
\hline & $(0.036)$ & (0.034) & (0.034) & $(0.032)$ & $(0.033)$ \\
\hline \multirow[t]{2}{*}{$I N V R$} & $-17.381 * *$ & $-17.305 * *$ & $-15.744 *$ & $-18.970 * *$ & $-18.022 * *$ \\
\hline & (7.231) & (8.685) & (8.340) & (7.663) & (7.866) \\
\hline \multirow[t]{2}{*}{$\Delta H P$} & $-0.450 * * *$ & $-0.473 * * *$ & $-0.456 * * *$ & $-0.459 * * *$ & $-0.461 * * *$ \\
\hline & $(0.142)$ & (0.149) & $(0.142)$ & $(0.145)$ & $(0.142)$ \\
\hline \multirow[t]{2}{*}{$\Delta I R$} & -0.385 & & & & \\
\hline & $(0.248)$ & & & & \\
\hline \multirow[t]{2}{*}{$R O P$} & & $-0.014 * *$ & & & \\
\hline & & $(0.005)$ & & & \\
\hline \multirow[t]{2}{*}{ IROR } & & & $-0.243^{*}$ & & \\
\hline & & & $(0.138)$ & & \\
\hline \multirow[t]{2}{*}{$\triangle L S O I$} & & & & 0.176 & \\
\hline & & & & $(0.133)$ & \\
\hline \multirow[t]{2}{*}{$T O B Q$} & & & & & -0.533 \\
\hline & & & & & $(0.629)$ \\
\hline \multirow[t]{2}{*}{ Constant } & 1.462 & 2.181 & 2.544 & 2.540 & $2.790 *$ \\
\hline & (1.879) & (1.670) & (1.707) & (1.635) & (1.611) \\
\hline
\end{tabular}

Panel B: Conditional marginal effects

\begin{tabular}{|c|c|c|c|c|c|}
\hline & Model 1 & Model 2 & Model 3 & Model 4 & Model 5 \\
\hline \multirow[t]{2}{*}{$\triangle C G D P$} & 0.004 & 0.003 & 0.003 & 0.006 & 0.005 \\
\hline & $(0.012)$ & $(0.010)$ & $(0.011)$ & $(0.012)$ & $(0.012)$ \\
\hline \multirow[t]{2}{*}{ CPIR } & $0.072 * * *$ & $0.057 * * *$ & $0.059 * *$ & $0.068 * * *$ & $0.064 * * *$ \\
\hline & $(0.022)$ & $(0.021)$ & (0.024) & $(0.024)$ & $(0.022)$ \\
\hline \multirow[t]{2}{*}{$M A$} & $-0.005^{*}$ & $-0.005 * *$ & $-0.006 * *$ & $-0.006 * *$ & $-0.006 * *$ \\
\hline & $(0.003)$ & $(0.002)$ & $(0.002)$ & (0.003) & (0.003) \\
\hline \multirow[t]{2}{*}{$I N V R$} & $-1.212 * *$ & -0.946 & -0.963 & $-1.273^{*}$ & $-1.281 *$ \\
\hline & $(0.610)$ & $(0.612)$ & (0.659) & (0.699) & (0.693) \\
\hline \multirow[t]{2}{*}{$\Delta H P$} & $-0.031 * * * *$ & $-0.026 * * * *$ & $-0.028 * *$ & $-0.031 * * *$ & $-0.033 * * *$ \\
\hline & $(0.011)$ & $(0.010)$ & $(0.011)$ & (0.010) & (0.010) \\
\hline \multirow[t]{2}{*}{$\Delta I R$} & -0.027 & & & & \\
\hline & $(0.018)$ & & & & \\
\hline \multirow[t]{2}{*}{$R O P$} & & $-0.001 * *$ & & & \\
\hline & & $(0.000)$ & & & \\
\hline \multirow[t]{2}{*}{$I R O R$} & & & $-0.015 *$ & & \\
\hline & & & $(0.008)$ & & \\
\hline$\triangle L S O I$ & & & & 0.012 & \\
\hline
\end{tabular}


$(0.008)$

\begin{tabular}{|c|c|c|c|c|c|}
\hline$T O B Q$ & & & & & $\begin{array}{l}-0.038 \\
(0.046)\end{array}$ \\
\hline Observations & 221 & 221 & 221 & 221 & 219 \\
\hline McFadden's pseudo- $\mathrm{R}^{2}$ & 0.464 & 0.480 & 0.471 & 0.453 & 0.445 \\
\hline AIC & 101.92 & 99.36 & 100.74 & 103.80 & 104.80 \\
\hline $\mathrm{BIC}$ & 125.71 & 123.15 & 124.52 & 127.59 & 128.52 \\
\hline Log-likelihood & -43.96 & -42.68 & -43.37 & -44.90 & -45.40 \\
\hline Wald stat. & $\begin{array}{l}44.11 * * * \\
{[0.000]}\end{array}$ & $\begin{array}{l}43.99 * * * \\
{[0.000]}\end{array}$ & $\begin{array}{l}41.81 * * * \\
{[0.000]}\end{array}$ & $\begin{array}{l}48.86 * * * \\
{[0.000]}\end{array}$ & $\begin{array}{l}49.37 * * * \\
{[0.000]}\end{array}$ \\
\hline Hosmer-Lemeshow stat. & $\begin{array}{l}4.74 \\
{[0.784]}\end{array}$ & $\begin{array}{l}3.58 \\
{[0.893]}\end{array}$ & $\begin{array}{l}1.58 \\
{[0.991]}\end{array}$ & $\begin{array}{l}4.88 \\
{[0.770]}\end{array}$ & $\begin{array}{l}4.51 \\
{[0.808]}\end{array}$ \\
\hline Correct recession $(50 \%)$ & $48.15 \%$ & $33.33 \%$ & $44.44 \%$ & $44.44 \%$ & $40.74 \%$ \\
\hline Correct non-recession $(50 \%)$ & $96.91 \%$ & $97.42 \%$ & $97.94 \%$ & $97.42 \%$ & $97.40 \%$ \\
\hline Correct overall (50\%) & $90.95 \%$ & $89.59 \%$ & $91.40 \%$ & $90.95 \%$ & $90.41 \%$ \\
\hline Correct recession $(12.16 \%)$ & $92.59 \%$ & $88.89 \%$ & $88.89 \%$ & $88.89 \%$ & $88.89 \%$ \\
\hline Correct non-recession (12.16\%) & $85.05 \%$ & $84.54 \%$ & $83.51 \%$ & $82.99 \%$ & $83.85 \%$ \\
\hline Correct overall (12.16\%) & $85.97 \%$ & $85.07 \%$ & $84.16 \%$ & $83.71 \%$ & $84.47 \%$ \\
\hline
\end{tabular}

Notes: Robust standard errors are given in parentheses. $p$-values are given in square brackets. ***, $* *$ and $*$ denote statistical significance at the 1,5 and $10 \%$ level, respectively. 


\section{Figures}

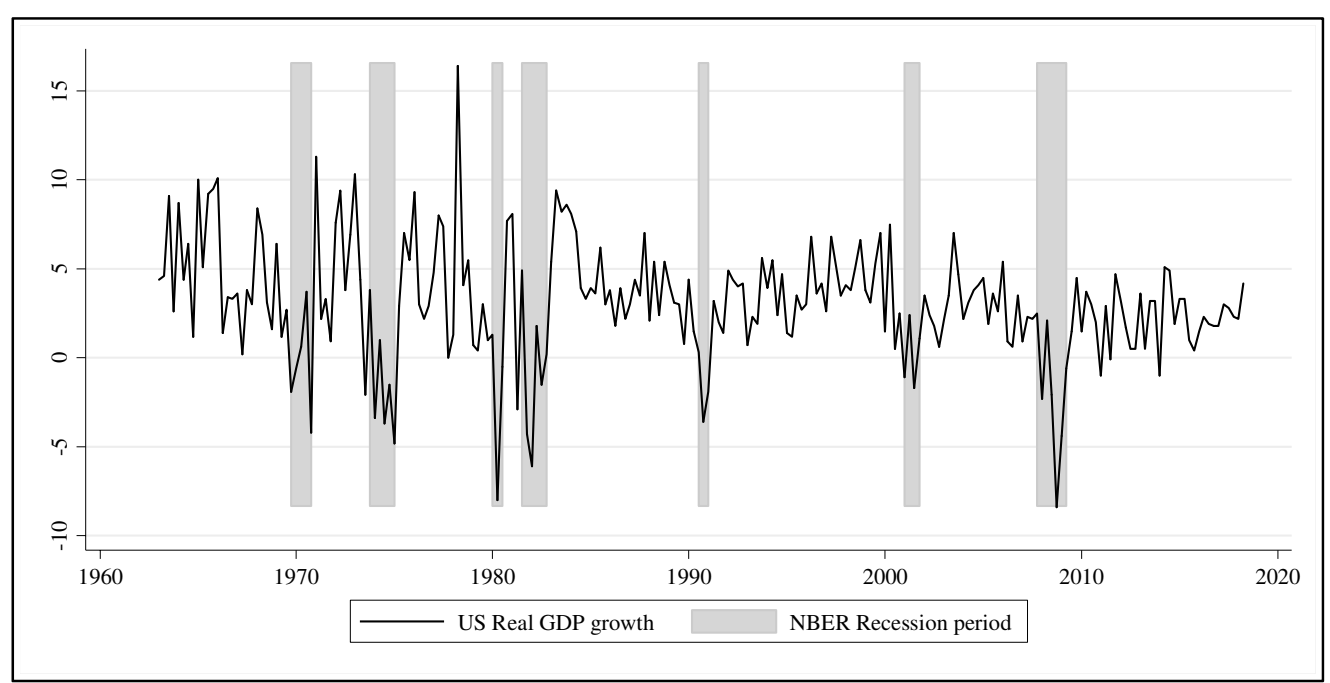

Fig. 1. US real GDP growth over the period 1963Q1-2018Q2 with NBER's recession reference periods. 

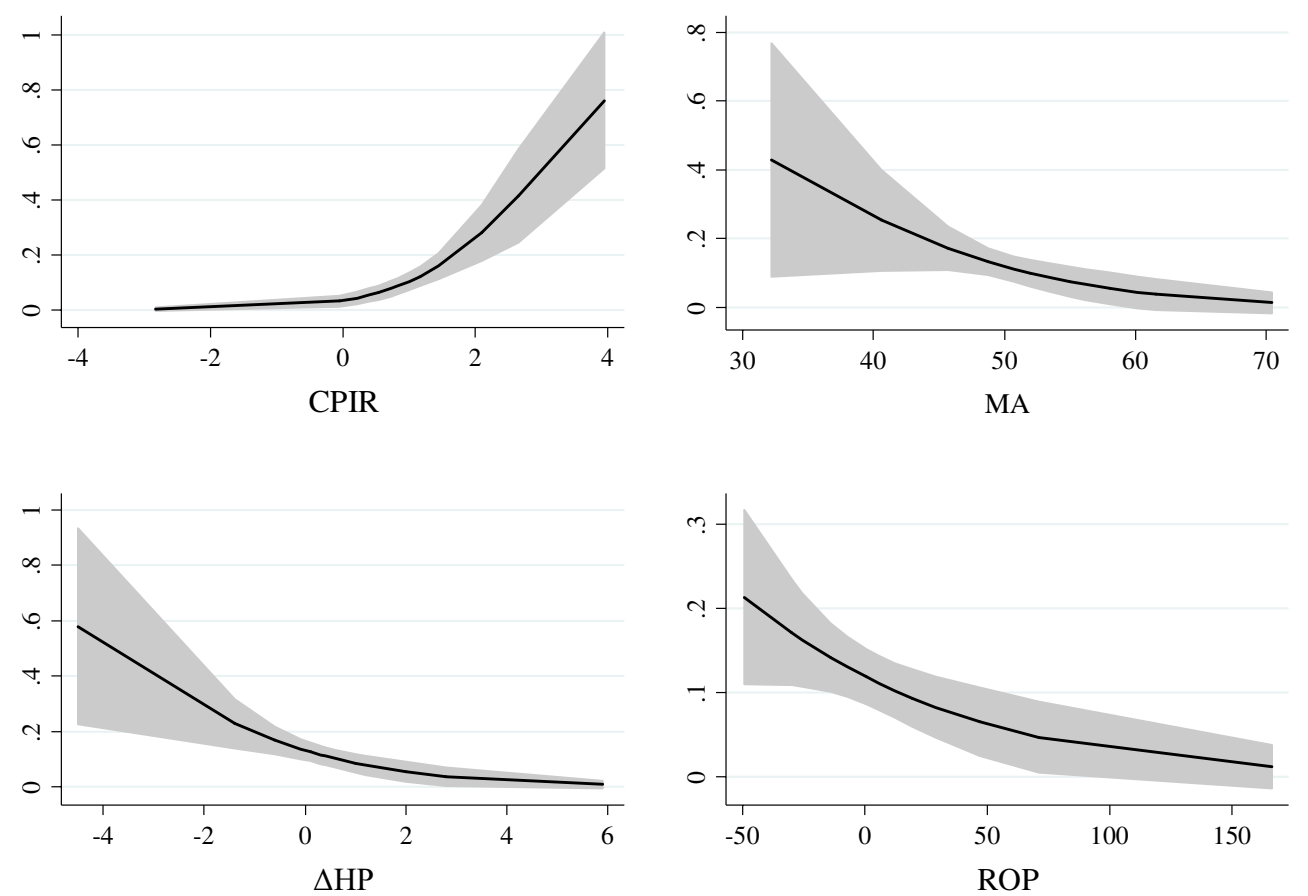

Fig. 2. The graphs of the marginal effects of the statistically significant variables in Model 2 (Table 1, Panel B) with 95\% confidence intervals (grey areas).

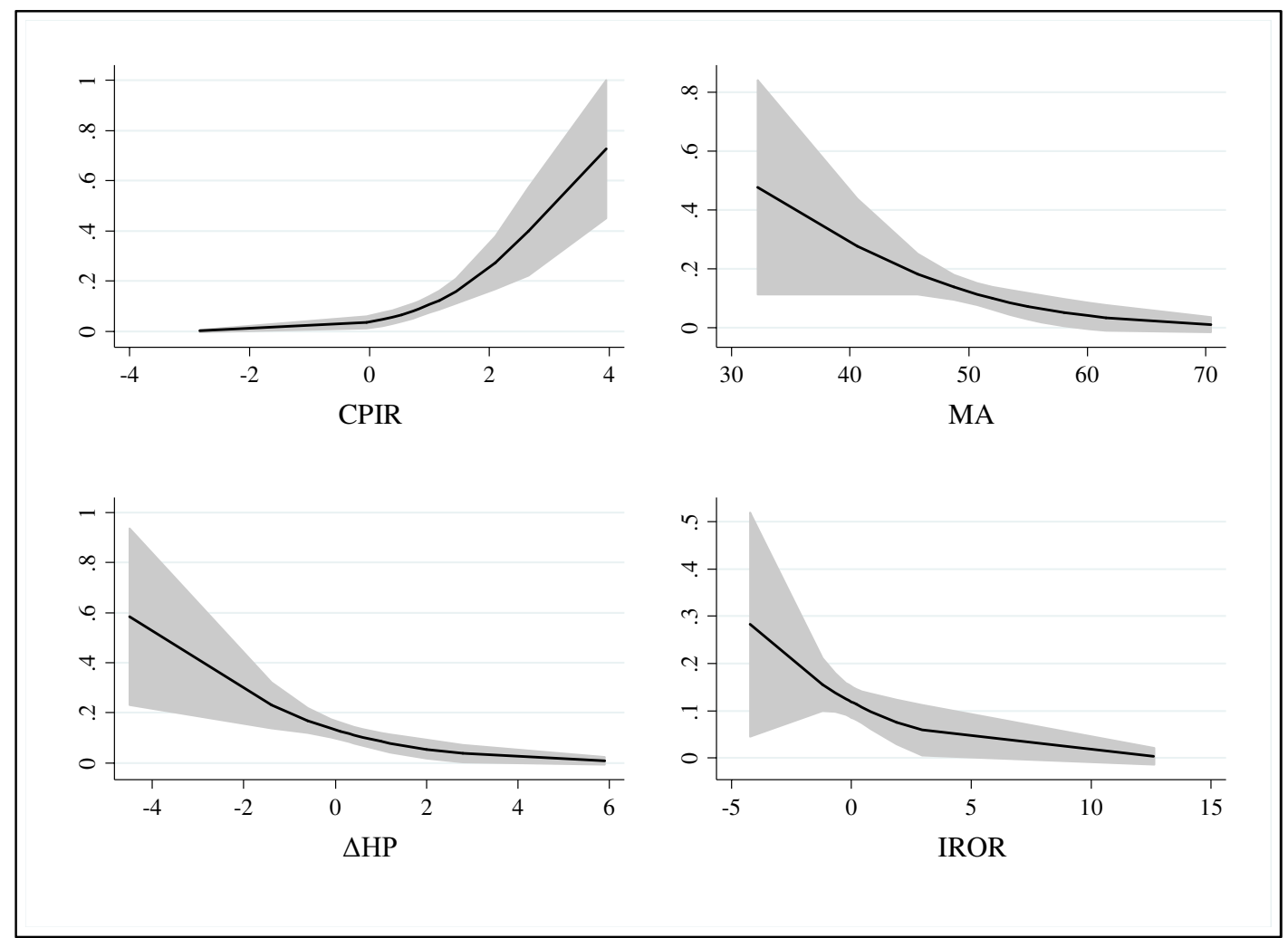

Fig. 3. The graphs of the marginal effects of the statistically significant variables in Model 3 (Table 1, Panel B) with 95\% confidence intervals (grey areas). 


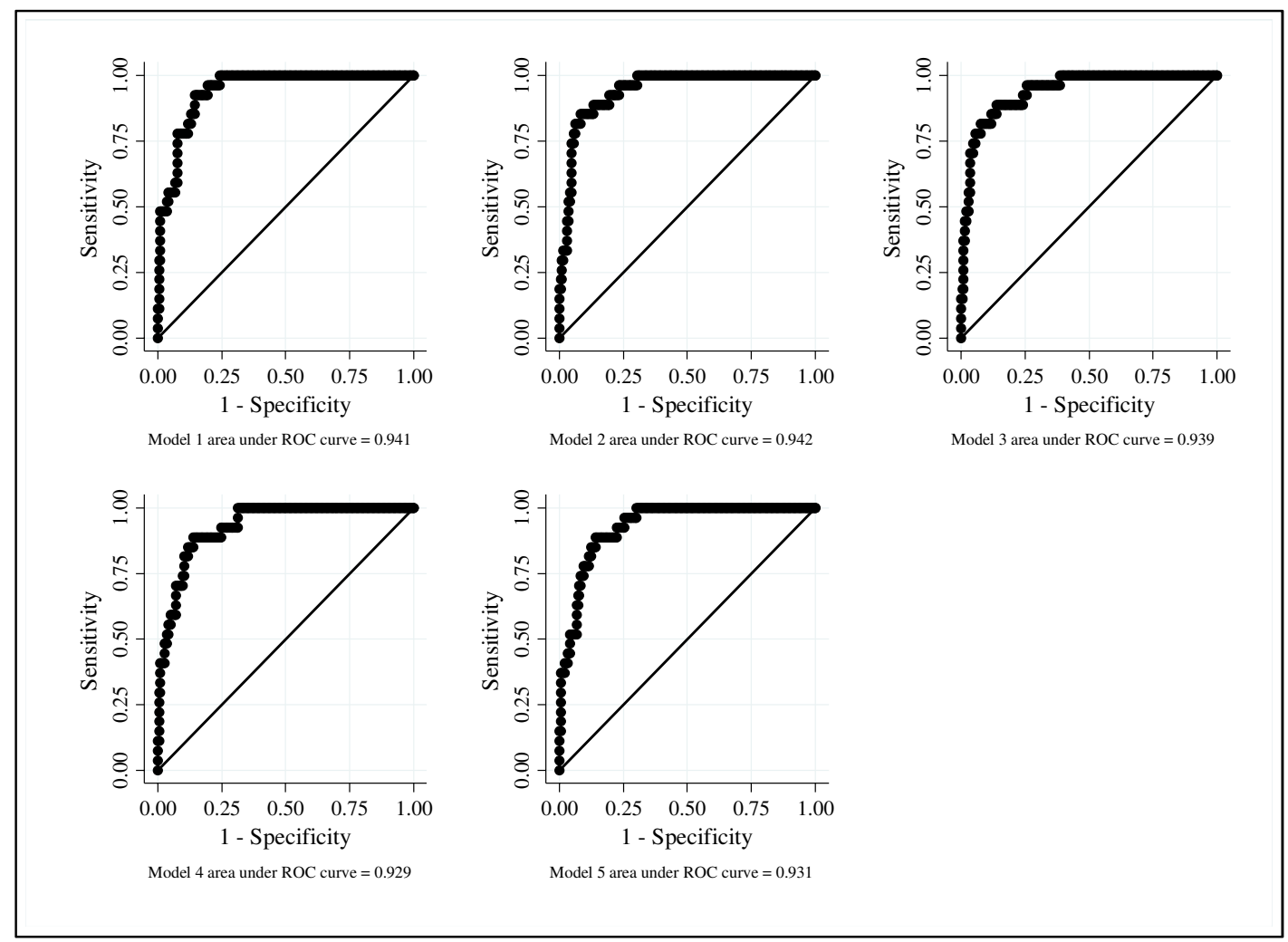

Fig. 4. The receiver operating characteristic (ROC) curves for Models 1 to 5. A model with no predictive power has an $\mathrm{AUC}=0.5$; a perfect model has an $\mathrm{AUC}=1$. 


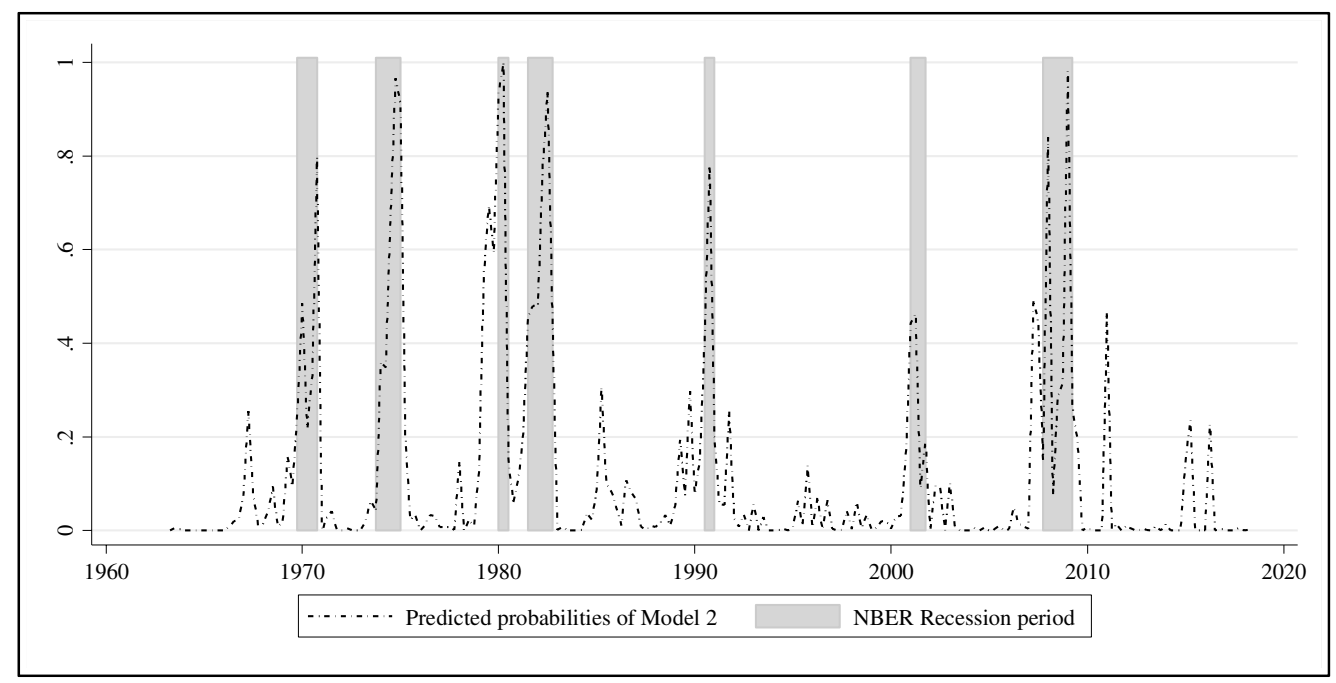

Fig. 5. The predicted probabilities of Model 2 with NBER's recession reference periods.

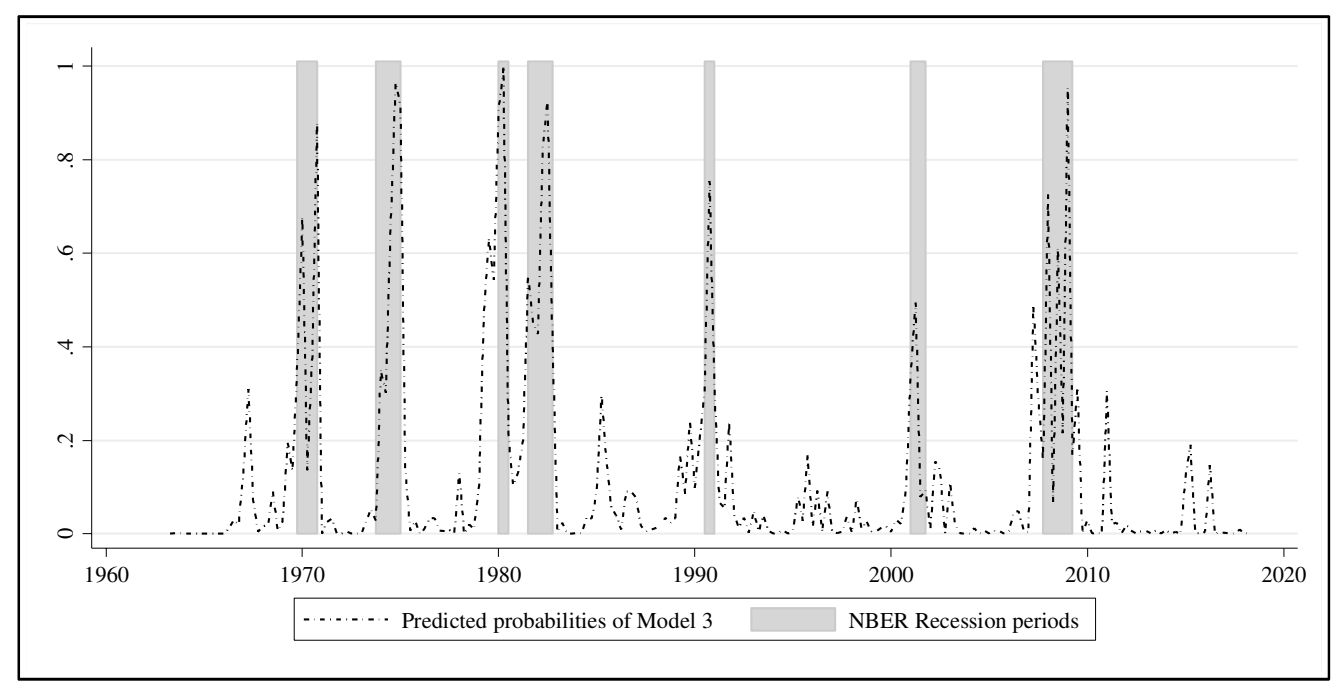

Fig. 6. The predicted probabilities of Model 3 with NBER's recession reference periods. 